\title{
STUDIA NAD LITERATURĄ WCZESNOCHRZEŚCIJAŃSKĄ W INSTYTUCIE FILOLOGII KLASYCZNEJ UNIWERSYTETU WARSZAWSKIEGO
}

Historia studiów nad literaturą wczesnochrześcijańską w Instytucie Filologii Klasycznej UW nie sięga zbyt daleko. Warunki, w jakich przyszło pracować i studiować na Uniwersytecie Warszawskim po II wojnie światowej nie sprzyjały, co oczywiste, rozwojowi takich studiów. Wprawdzie już w r. 1966 ks. Marek Starowieyski napisał pod kierunkiem prof. K. Kumanieckiego pracę o Izydorze z Sewilli ${ }^{1}$, którą faktycznie opiekował się mgr T. Brzostowski, a kilka lat wczesniej ówczesny student Jerzy Wojtczak skromną pracę o stosunku Laktancjusza do filozofii starożytnej, to nawet obroniona na przełomie roku 1966/67 praca doktorska tegoż samego autora: De Lactantio Ciceronis aemulo et sectatore ${ }^{2}$, nie była jeszcze impulsem do szerszych badań i zainteresowania ze strony studentów. Dopiero na początku lat osiemdziesiątych udało mi się zorganizować konwersatorium, w którym brało udział początkowo kilkoro, a potem kilkanaścioro studentów, z którymi czytałem i omawiałem najpierw tekst Laktancjusza Divinae Institutiones (przez krótki czas), a potem rozmaite teksty zamieszczone w Roma Christiana prof. L. Małunowiczówny, a także współczesne już dokumenty; przestudiowaliśmy w ten sposób i omówiliśmy dokładnie całą publikację Concilio vitam alere. Meditationes super decretis Concilii Vaticani II a Cardinali Pericle Felici ordine dispositae, gdzie są przecież liczne odniesienia do Pisma św. i pism Ojców Kościoła oraz do dawnych dokumentów kościelnych, a także Adhortację Apostolicam actuositatem, wskazówki i rady Ignacego oraz fragmenty szeregu innych dawniejszych i współczesnych łacińskich tekstów o proweniencji eklezjastycznej. W tym też czasie za radą ks. M. Starowieyskiego podjęliśmy wspólnie pracę nad przekładem Vitae Patrum Iurensium, które stały się pierwszym tomem znakomicie dzisiaj rozwiniętej i obfitującej w świetne przekłady wybitnych dzieł z zakresu monastycyzmu serii „Źródła monastyczne", pozostającej w gestii Wydawnictwa Benedyktynów w Tyńcu, nad którą naukową kuratelę sprawuje właśnie ks. M. Starowieyski.

${ }^{1}$ Por. Obraz klasycznej literatury pogańskiej w dziełach Izydora z Sewilli, 1966.

${ }^{2}$ Por. De Lactantio Ciceronis aemulo et sectatore, Wrocław-Warszawa-Kraków 1969, ss.70. 
Krąg zainteresowanych studiami patrystycznymi zaczął się powoli poszerzać, a moje zabiegi i starania o wprowadzenie wykładów i seminariów z tego zakresu mogły wreszcie doczekać się realizacji dzięki przychylności władz instytutu i wydziału. Właśnie wtedy powołany został do pracy w Instytucie Filologii Klasycznej ks. prof. dr hab. M. Starowieyski, który rozpoczął wykłady z literatury wczesnochrześcijańskiej (pewien wykład sięgający tematyki biblijnej objął nawet studentów polonistyki) oraz prowadzenie z niej seminarium, ja zaś zapoczątkowałem prowadzenie seminarium z literatury wczesnochrześcijańskiej o charakterze językowym. W ten sposób - nigdy sobie przedtem tego nawet nie wyobrażano - w IFK UW zaistniały dwa seminaria związane ze spuścizną Ojców Kościoła i pisarzy kościelnych, co jest niewątpliwie wielkim sukcesem tej dyscypliny w Polsce, myślę, że trochę nie docenianym w gronie naszych badaczy. Trzeba też powiedzieć, że zainteresowanie wykładami i seminariami z zakresu patrystyki nie wynika wcale z jakiejś szczególnej reklamy czy atmosfery studiów - jest ono jakby spontanicznym wyjściem naprzeciw właściwie pomyślanej inicjatywie, która znajduje odzew u słuchaczy.

$\mathrm{Na}$ tym tle należy wspomnieć o tematach prac magisterskich podejmowanych przez studentów. Ks. Marek Starowieyski był już promotorem jednej pracy, dziewięć prac zostało podjętych pod moją opieką. Trzy osoby otrzymały już tytuł magistra filologii klasycznej na podstawie przedstawionych studiów: jedna z nich omawiała problematykę cnoty czystości w Divinae Institutiones Laktancjusza $^{3}$, druga - zajmowała się symboliką Feniksa w poemacie Laktancjusza De ave Phoenice ${ }^{4}$, trzecia zaś brzmiała: Sposoby oddawania przez Tertuliana rzeczowników i przymiotników greckich z alpha privativum ${ }^{5}$. Podkreślam $\mathrm{z}$ całą odpowiedzialnością, że były to prace na wysokim poziomie, a dwie ostatnie bez wątpienia kwalifikowały się do druku (jedna $z$ nich już jest w druku). W ślad za magisterskimi poszła też jedna, obroniona w ubiegłym roku, rozprawa doktorska p.t. Architektura jezzykowa dzieła Arnobiusza z Sikka «Adversus nationes» ${ }^{6}$. Praca ta, której byłem promotorem, została przygotowana praktycznie samodzielnie przez młodego, wybitnie zdolnego badacza, na takim poziomie, że może być zaprezentowana w każdym ośrodku naukowym na świecie. Obecnie dwie inne osoby, nad którymi sprawuję opieką naukową, podjęły się przygotowania prac doktorskich z zakresu patrystyki. Na Wydziale Polonistyki, do którego należy Instytut Filologii Klasycznej UW, miała też miejsce przed dwoma laty habilitacja ks. Antoniego Swobody, który przedstawil dysertację p.t. Pojęcie przyjaźni $w$ listach św. Paulina z Noli i Sydoniusza

3 J. Gredecka, Wartość czystości i życia matżeńskiego w „Divinae Institutiones” Laktancjusza, 1994.

${ }^{4}$ J. Tomoń, Symbolika Feniksa w poemacie Laktancjusza „De ave Phoenice”, 1995.

${ }^{5}$ B. Chądzyńska, Sposoby oddawania przez Tertuliana rzeczowników i przymiotników greckich z alpha privativum, 1998.

${ }^{6}$ W 1998 roku. 
Apolinarego (1996). Obszerna rozprawa ks. Swobody wypełnia w pewnej mierze lukę w studiach polskich patrologów nad tak wybitnymi postaciami starożytności chrześcijańskiej. Parę słów należy się też bibliotece Instytutu: liczy ona obecnie ponad trzydzieści tysięcy tomów i choć pozycje związane z pismami Ojców Kościoła nie są jeszcze zbyt liczne, bo nie gromadzono ich przedtem, to przecież liczba książek i czasopism związanych z tą problematyką stale rośnie; regularnie dociera tam również VOX PATRUM. Zdarzają się też pozycje ofiarowane przez inne ośrodki lub prywatne osoby.

Trzeba wreszcie wspomnieć o korzystnych zmianach w lekturach studenckich: od kilku lat widnieją w ich spisie przynajmniej dwie pozycje: krótki wybór z greckiego tekstu Nowego Testamentu i fragment Confessiones św. Augustyna. Można jeszcze postawić pytanie: jakie są perspektywy kontynuowania czy ewentualnego poszerzania tego programu? Obecne częste zmiany ratio studiorum nie dają możliwości prognozowania, wydaje się jednak, że tendencja do pewnego ustabilizowania się pozycji elementu patrystycznego w studiach filologii klasycznej istnieje i będzie zależeć od osób, które potrafią ją podtrzymać. Ufamy, że osoby te odnajdziemy.

\title{
DE LITTERARUM CHRISTIANARUM STUDIIS IN INSTITUTO PHILOLOGIAE CLASSICAE UNIVERSITATIS STUDIORUM VARSAVIENSIS NUPER INCHOATIS
}

\author{
(Argumentum)
}

Veterum Patrum et scriptorum ecclesiasticorum doctrina in Instituto Philologiae Classicae Universitatis Studiorum Varsaviensis tum demum reapse tractari est coepta, cum mutato rei publicae statu et ipsis viris doctis et iuvenibus studiosis nova educandi via aperiebatur dabaturque facultas. Itaque iam nunc duo seminaria legendis istorum auctorum operibus instituta sunt et scholae habentur, quibus de eorum textu, lingua et stilo disseritur quibusque praecipuae illorum auctorum doctrinae theses disputantur. Hoc etiam tempore nonnulla meletemata, articuli et libri divulgati sunt, quae ad varias quaestiones solvendas aspectabant. Plures sunt quoque auditores, qui ad haec studia fovenda vel proprio ingenio vel curiositate incitantur. 